\title{
I 131 Monoclonal Antibody CC49
}

National Cancer Institute

\section{Source}

National Cancer Institute. I 131 Monoclonal Antibody CC49. NCI Thesaurus. Code C26442.

A radioimmunoconjug ate of the humanized monoclonal antibody CC49 labeled with iodine I 131. Iodine I 131 monoclonal antibody CC49 delivers beta and gamma radiationemitting I 131 radionuclide specifically to tumor cells that express tumor-associated glycoprotein (TAG)-72, allowing localization of TAG-72-expressing tumor cells with radioimaging devices in diagnostic applications or resulting in specific TAG-72-expressing tumor cell radiocytotoxicity in therapeutic applications. Monoclonal antibody CC49 binds to TAG-72, a pancarcinoma antigen, with high affinity. 